\title{
Lignite fired fly ash modified by chemical treatment for adsorption of zinc from aqueous solution
}

\author{
T. S. Malarvizhi $\cdot$ T. Santhi
}

Received: 7 July 2012/ Accepted: 16 August 2012/Published online: 2 September 2012

(C) The Author(s) 2012. This article is published with open access at Springerlink.com

\begin{abstract}
The purpose of the study described in this paper was to compare removal of $\mathrm{Zn}$ (II) from aqueous solutions by use of two adsorbents-alkali-modified fly ash (FAN) and alkali and dye-modified fly ash (FAN-MO). The effects of four conditions (solution $\mathrm{pH}$, contact time, initial metal ion concentration, and dose of adsorbent) on removal of $\mathrm{Zn}$ (II) at $27 \pm 5{ }^{\circ} \mathrm{C}$ were studied in batch mode. Adsorption of $\mathrm{Zn}(\mathrm{II})$ was greater at $\mathrm{pH} 4.0$ for FAN $(76.49 \%)$ and at $\mathrm{pH} 5.0$ for FAN-MO (24.72\%). Maximum adsorption of $\mathrm{Zn}(\mathrm{II})$ by FAN and FAN-MO was achieved after 50 min. The linear forms of the Langmuir, Freundlich, Tempkin, D-R, Harkin-Jura, and Frenkel-Halsey isotherms were used for experiments with different concentrations of the metals. Adsorption of $\mathrm{Zn}$ (II) ions satisfied the Langmuir isotherm model only. The adsorption capacity of both adsorbents was also investigated by column studies. Adsorption of $\mathrm{Zn}$ (II) ions on FAN in column studies $(45.33 \%)$ was lower than in batch mode studies. For FAN-MO, adsorption was $37.88 \%$ in column studies, again lower than in batch mode studies. Fly ash modified by alkali had a higher adsorption capacity for $\mathrm{Zn}$ (II) ions than fly ash modified by alkali followed by addition of dye.
\end{abstract}

Keywords Adsorption · Isotherms · Kinetics · Column studies · Zn(II)

\section{Introduction}

Fly ash is an amorphous mixture of ferroaluminosilicate minerals generated by combustion of ground or powdered coal [1]. Approximately $70 \%$ of the combustion by-products is fly ash collected in electrostatic precipitators. This is the most difficult by-product to handle [2], and there is a need for environment-friendly uses

T. S. Malarvizhi · T. Santhi (西)

Department of Chemistry, Karpagam University, Coimbatore 641021, India

e-mail: ssnilasri@yahoo.co.in 
of fly ash. Fly ash is mostly used as a substitute for Portland cement in the manufacture of roofing tiles and as structural fill, sheetrock, and agricultural fertilizer, and for soil amendment [3, 4]. Chemically, 90-99 \% of fly ash comprises $\mathrm{Si}, \mathrm{Al}, \mathrm{Fe}, \mathrm{Ca}, \mathrm{Mg}, \mathrm{Na}$, and $\mathrm{K}$, with $\mathrm{Si}$ and $\mathrm{Al}$ being the major components. The mineralogical, physical, and chemical properties of fly ash depend on the nature of the parent coal $[5,6]$. The applications of fly ash depend on the presence of basic mineral elements resembling the earth's crust, which makes it an excellent substitute for natural materials. Use of fly ash for removal of heavy metals from waste waters in the dye-finishing industry generates a supplementary problem, related to the affinity of the dyes for oxide surfaces. Studies have proved that further conditioning by alkali treatment can be needed to enhance the efficiency of adsorption on fly ash of heavy metals [7] or multi component systems of heavy metals and dyes. Highly efficient removal of heavy metals has been achieved by use of fly ash treated with $2 \mathrm{M} \mathrm{NaOH}$ solutions [8]. Some dyes fixed on the fly ash surface ( $\mathrm{NaOH}$-treated fly ash) can act as complexing agents, increasing the efficiency of adsorption of heavy metals.

Heavy metals are present in wastewaters because of discharge by industry, for example electroplating, inorganic pigment manufacture, wood processing, photographic operations, and petroleum refining. Heavy metals are also used in rubber, pesticides, and plastics. Many compounds of the heavy metals are readily soluble in water and can be adsorbed by living organisms in the food chain. Small amounts of some heavy metals (copper, cobalt, iron, manganese, vanadium, strontium, and zinc) are needed by living organisms, but excessive levels of essential metals can be detrimental to the organisms and cause serious health effects (cancer, liver damage, renal disorder, visceral cancers, insomnia, depression, lethargy, vomiting) [9]. Children, in particular, are at risk; consumption of food containing excessive amounts of heavy metals can result in reduction of growth and damage to the nervous system and brain. Although $\mathrm{Zn}$ (II) is regarded as relatively nontoxic (it is a co-factor in over 100 enzyme reactions) its excessive inhalation (as fumes) may cause diseases. The toxicity symptoms-nausea, vomiting, yellow skin and eyes, "zinc chills", epigastria pain, lethargy, neuropathy, low blood pressure, and fatigue-appear when $\mathrm{Zn}$ intake is high. To minimize human and environmental exposure to hazardous heavy metals the US Environmental Protection Agency (US EPA) established limits of cadmium, lead, and zinc that may be discharged into wastewater at $0.01,0.006$, and 0.80 , respectively. Heavy metals can deactivate the active sludge (by poisoning the bacteria) in secondary treatment plants [10]; therefore, chemical treatment must be used to remove heavy metals before the biological step. The method most common and widely used for removing heavy metals from wastewater is chemical precipitation by use of caustic soda or lime [11]. This method is not expensive but requires a large amount of chemicals and results in a large quantity of sludge that requires supplementary treatment. Moreover, depending to the precipitate's solubility, the residual amount of dissolved heavy metal may exceed the discharge limit. Replacing synthetic substrates with low-cost adsorbents has, therefore, been intensively studied, and there have been reports of the use of materials obtained from agriculture and from forest wastes, for example bagasse fly ash [12], sugar beet pulp [13], activated carbon derived from 
bagasse [14], maple sawdust [15], clay [16, 17], volcanic ash bone char [18], humus [19], or bituminous coal, for removal of heavy metals. Removal of heavy metals (cadmium, copper, zinc, and nickel) on scrap rubber, bituminous coal, peat [20], and natural zeolite [21] has also been reported.

In this paper we report a comparative study of the efficiency of $\mathrm{Zn}$ (II) uptake on fly ash modified by treatment with alkali (4 M NaOH) (FAN) and on fly ash modified by treatment with alkali then methyl orange (FAN-MO). The adsorption kinetics were studied. Substrate capacity is discussed, and is correlated with surface structure (SEM and EDAX) by batch and column study.

\section{Materials and methods}

Preparation of adsorbents

The fly ash used for this study was collected from the NLC Power Plant, Neyveli, Tamil Nadu, India. One part of the fly ash was treated with $4 \mathrm{M} \mathrm{NaOH}$ and then stirred magnetically at $90{ }^{\circ} \mathrm{C}$ for $1 \mathrm{~h}$. The solution was left to settle for $24 \mathrm{~h}$ then washed repeatedly with distilled water until the conductivity of the filtrate was $<300 \mu \mathrm{s}$. It was then filtered and dried in a hot air oven at $105^{\circ} \mathrm{C}$. The dried alkali-treated fly ash (FAN) was then powdered, ground, and used for further studies [22]. It was divided into two parts. One part was used as such. The other part was treated with methyl orange dye for $48 \mathrm{~h}$ at room temperature. After isolation by filtration it was flushed with distilled water, and dried. This material (FAN-MO) also was used for adsorption of $\mathrm{Zn}(\mathrm{II})$ ions. The yield of FAN was $95.3 \%$ and that of FAN-MO was $96 \%$.

Preparation of adsorbate

Zinc sulfate heptahydrate $\left(\mathrm{ZnSO}_{4} \cdot 7 \mathrm{H}_{2} \mathrm{O}\right)$ and nickel sulfate hexahydrate $\left(\mathrm{NiSO}_{4}\right.$. $6 \mathrm{H}_{2} \mathrm{O}$ ) were purchased from Spectrum Reagents and Chemicals (Adayar, Aluva, India). Copper sulfate pentahydrate $\left(\mathrm{CuSO}_{4} \cdot 5 \mathrm{H}_{2} \mathrm{O}\right), \mathrm{NaOH}, \mathrm{HCl}$, and $\mathrm{HNO}_{3}$, were obtained from S D Fine-Chem (Mumbai, India) and used without further purification. Stock solutions were $1 \mathrm{~g} / \mathrm{L}$. Double-distilled water was used throughout the study.

Characterization of the adsorbent

\section{Iodine value of the adsorbent}

Iodine number ( $\mathrm{mg} / \mathrm{g}$ adsorbent), which indicates the extent of micro pore distribution in the adsorbent, was determined by use of standard $0.1 \mathrm{M}$ iodine solution. The titrant used was $0.1 \mathrm{M}$ sodium thiosulfate.

\section{Fourier-transform infrared analysis}

Functional groups in FAN and FAN-MO were determined by use of FTIR spectroscopy, at room temperature, by use of a Spectrum RX1 "Pelmer" version 5.3 Spectrophotometer in the spectral range $4,000-400 \mathrm{~cm}^{-1}$ with resolution of $4 \mathrm{~cm}^{-1}$. 
Adsorption and kinetic studies

A stock solution of $\mathrm{ZnSO}_{4} \cdot 7 \mathrm{H}_{2} \mathrm{O}(1,000 \mathrm{mg} / \mathrm{L})$ was prepared and diluted to appropriate initial concentrations. Adsorption studies were conducted at room temperature $\left(28 \pm 5{ }^{\circ} \mathrm{C}\right)$. Batch adsorption studies were conducted by mixing $0.2 \mathrm{~g}$ fly ash in a bottle with $50 \mathrm{~mL}$ solution of the required concentration by use of a bench shaker at a fixed shaking speed of $120 \mathrm{rpm}$. Solution $\mathrm{pH}$ varied from 2 to $10 ; \mathrm{pH}$ was adjusted by use of $0.1 \mathrm{M} \mathrm{HCl}$ and $0.1 \mathrm{M} \mathrm{NaOH}$. The resulting mixture was filtered (Whatman filter paper no. 41) and the final concentration of the metal ions in the filtrate was determined by use of a UV-2450 vis spectrophotometer. Experiments were performed with different amounts of adsorbent, different initial $\mathrm{Zn}$ (II) concentrations, for different contact times, and at different initial $\mathrm{pH}$ of the solution. From the initial and final concentrations, percentage removal can be calculated by use of the formula:

$$
\% \text { of removal }=\frac{\left(C_{\mathrm{o}}-C_{\mathrm{f}}\right) \times 100}{C_{\mathrm{o}}}
$$

where $C_{\mathrm{o}}$ is the initial concentration of $\mathrm{Zn}(\mathrm{II})$ ions in $\mathrm{mg} / \mathrm{L}$ and $C_{\mathrm{f}}$ is the final concentration of $\mathrm{Zn}(\mathrm{II})$ ions in $\mathrm{mg} / \mathrm{L}$. The results obtained in batch mode were used to calculate the equilibrium metal uptake capacity. The uptake capacity for $\mathrm{Zn}$ (II) ions was calculated by use of the formula:

$$
q_{\mathrm{e}}=\frac{v \times\left(C_{\mathrm{o}}-C_{\mathrm{e}}\right)}{w}
$$

where $q_{\mathrm{e}}$ is the equilibrium uptake capacity in $\mathrm{mg} / \mathrm{g}, v$ is the sample volume in litres, $C_{\mathrm{o}}$ is the initial metal ion concentration in $\mathrm{mg} / \mathrm{L}, C_{\mathrm{e}}$ the equilibrium metal ion concentration in $\mathrm{mg} / \mathrm{L}$, and $w$ is the dry weight of adsorbent in grams.

\section{Adsorption isotherms}

Equilibrium studies were undertaken to understand the behaviour of the adsorbent under equilibrium conditions. Equilibrium data are a basic requirement for the design of adsorption systems and adsorption models, which are used for the mathematical description of the adsorption equilibrium of the metal ion by the adsorbent. The results obtained for adsorption of $\mathrm{Zn}$ (II) ions were analysed by use of well-known models given by the Langmuir, Freundlich, Tempkin, DubininRadushkevich, Harkin-Jura, and Frenkel-Halsey-Hill isotherms. For the sorption isotherms, initial metal ion concentration was varied whereas solution $\mathrm{pH}$ and amount of adsorbent were held constant. The sorption isotherms for $\mathrm{Zn}$ were obtained for FAN at solution at $\mathrm{pH} 4$ and FAN-MO at $\mathrm{pH} 5$.

\section{Langmuir isotherm}

The Langmuir isotherm assumes monolayer adsorption by a surface containing a finite number of adsorption sites [23]. The linear form of Langmuir equation is: 


$$
\frac{C_{\mathrm{e}}}{q_{\mathrm{e}}}=\frac{1}{Q_{\mathrm{e}} K_{\mathrm{L}}}+\frac{1}{Q_{\mathrm{e}}} C_{\mathrm{e}}
$$

where $Q_{\mathrm{e}}(\mathrm{mg} / \mathrm{g})$ and $K_{\mathrm{L}}\left(\mathrm{dm}^{3} / \mathrm{g}\right)$ are the Langmuir constants related to adsorption capacity and rate of adsorption.

\section{Freundlich isotherm}

The Freundlich isotherm assumes heterogeneous surface energy; in this isotherm the energy term of the Langmuir equation varies as a function of surface coverage [24]. The well-known logarithmic form of the Freundlich isotherm is given by:

$$
\log q_{\mathrm{e}}=\log K_{\mathrm{F}}+\frac{1}{n} \log C_{\mathrm{e}}
$$

where $K_{\mathrm{F}}(\mathrm{mg} / \mathrm{g})(1 / \mathrm{mg})$ and $1 / n$ are the Freundlich adsorption constant and a measure of the adsorption intensity.

\section{Tempkin isotherm}

The Tempkin isotherm assumes that the heat of adsorption (a function of temperature) of all molecules in the layer decreases linearly, rather than logarithmically, with coverage. Its derivation is characterized by a uniform distribution of binding energies (up to a maximum binding energy) [25]. The Tempkin isotherm has been used in the form of:

$$
q_{\mathrm{e}}=B \ln A+B \ln C_{\mathrm{e}}
$$

where $B=R T / b, b$, and $A, R$, and $T$ are the Tempkin constant related to the heat sorption $(\mathrm{J} / \mathrm{mol})$, the equilibrium binding constant $(\mathrm{l} / \mathrm{g})$, the gas constant $(8.314 \mathrm{~J} /$ $\mathrm{mol} \mathrm{K}$ ) and the absolute temperature $(\mathrm{K})$.

\section{Dubinin-Radushkevich isotherm}

The D-R model was used to estimate the porosity, apparent free energy, and characteristics of adsorption [26-28]. The D-R isotherm does not assume a homogeneous surface or a constant adsorption potential. The $\mathrm{D}-\mathrm{R}$ model is commonly applied by use of Eq. (6) and its linear form, Eq. (7):

$$
\begin{gathered}
q_{(e)}=Q_{m} \exp \left(-K \varepsilon^{2}\right) \\
\ln q_{e}=\ln Q_{m}-K \varepsilon^{2}
\end{gathered}
$$

where $K$ is a constant related to the adsorption energy, $Q_{\mathrm{m}}$ the theoretical saturation capacity, and $\varepsilon$ the Polanyi potential, calculated by use of Eq. (8):

$$
\varepsilon=R T \ln \left(1+\frac{1}{C_{\mathrm{e}}}\right)
$$

The slope of the plot of $\ln q_{\mathrm{e}}$ versus $\varepsilon^{2}$ gives $K\left(\mathrm{~mol}^{2} /\left(\mathrm{kJ}^{2}\right)\right)$ and the intercept yields the adsorption capacity, $Q_{\mathrm{m}}(\mathrm{mg} / \mathrm{g})$. The mean free energy of adsorption $(E)$, 
defined as the free energy change when one mole of ion is transferred from infinite concentration in solution to the surface of the solid, was calculated from the $K$ value by use of the relationship [29].

$$
E=\frac{1}{\sqrt{ } 2 K}
$$

\section{Harkin-Jura adsorption}

The Harkin-Jura adsorption isotherm can be expressed as:

$$
\frac{1}{q_{\mathrm{e}}^{2}}=\left(\frac{B_{2}}{A}\right)-\left(\frac{1}{A}\right) \log C_{\mathrm{e}}
$$

where $B_{2}$ is the isotherm constant. $1 / q_{\mathrm{e}}^{2}$ was plotted versus $\log C_{\mathrm{e}}$. This isotherm explains multilayer adsorption on the basis of the existence of a heterogeneous pore distribution [30].

\section{Frenkel-Halsey-Hill isotherm}

The Frenkel-Halsey-Hill isotherm can be expressed as:

$$
\ln q_{\mathrm{e}}=\frac{1}{n} \ln K-\frac{1}{n} \ln C_{\mathrm{e}}
$$

$\ln q_{\mathrm{e}}$ was plotted versus $\ln C_{\mathrm{e}}$. This isotherm explains the multilayer adsorption on the basis of the existence of a heterogeneous pore distribution of the adsorbent [31].

\section{Results and discussion}

Characterization of adsorbents

\section{Scanning electron microscopic studies (SEM)}

Figures 1a and 2 clearly show the physical morphology of FAN and FAN-MO as observed by SEM at $1,000 \times$ magnification. The fly ash particles are primarily spherical whereas the alkali-treated FAN and FAN-MO fly ash particles are mainly composed of irregular and porous particles, respectively, before adsorption. The SEM image in Fig. 1b shows the fly ash morphology of FAN after adsorption. The square box in Fig. 1b shows $\mathrm{Zn}$ (II) ions surrounded by FAN, which proves adsorption of $\mathrm{Zn}(\mathrm{II})$ ions by the FAN surface.

\section{EDAX elemental analysis}

The major components of $\mathrm{FAN}$ were $\mathrm{SiO}_{2} 36.89 \%, \mathrm{Al}_{2} \mathrm{O}_{3} 33.04 \%, \mathrm{CaO} 16.37 \%$, $\mathrm{MgO} 4.77 \%, \mathrm{TiO}_{3} 1.38 \%, \mathrm{FeO} 1.85 \mathrm{Na}_{2} \mathrm{O} 5.71 \%$. For FAN-MO they were $\mathrm{SiO}_{2}$ $33.76 \%, \mathrm{Al}_{2} \mathrm{O}_{3} 38.36 \%, \mathrm{CaO} 17.40 \%, \mathrm{MgO} 4.99 \%, \mathrm{TiO}_{3} 1.73 \%$, and $\mathrm{FeO}$ 
Fig. 1 a SEM image of FAN before adsorption. b SEM image of FAN after adsorption
Fig. 2 SEM image

of FAN-MO before adsorption
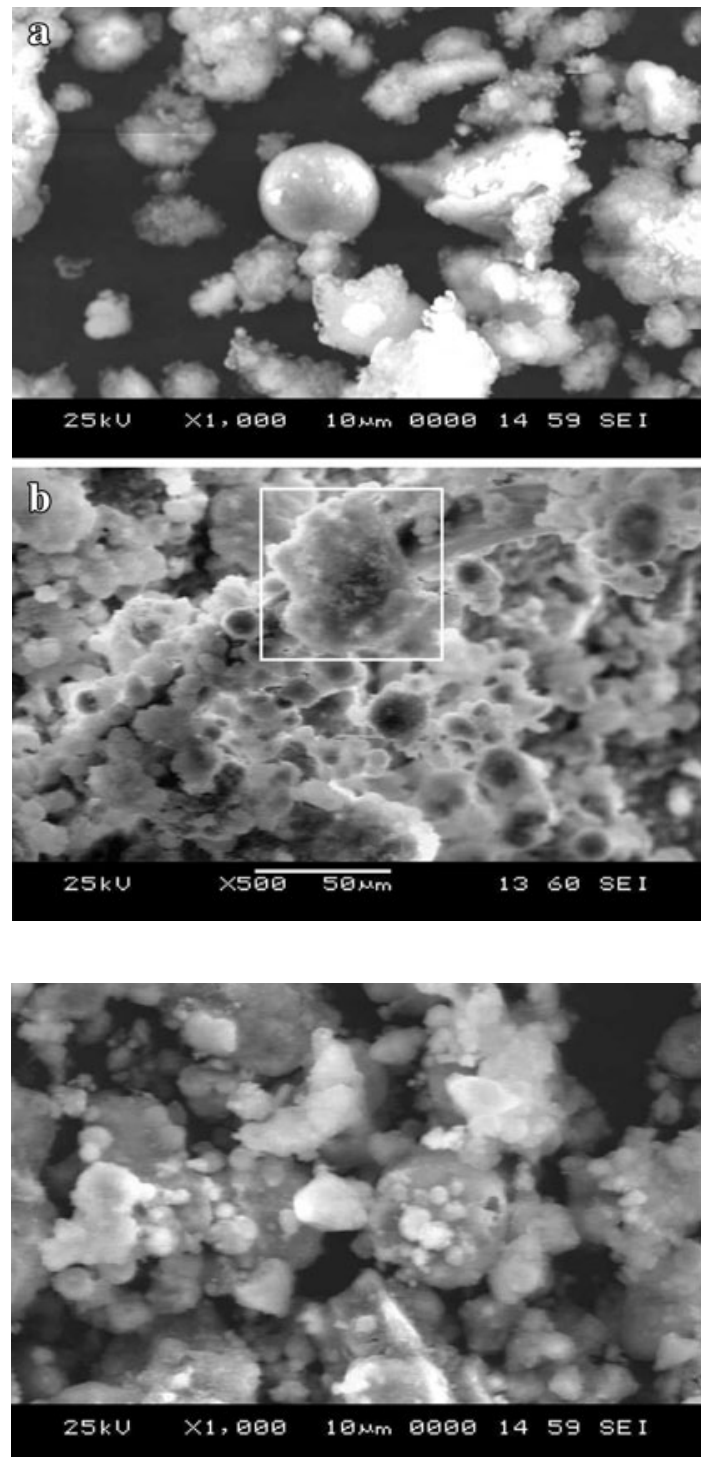

$3.76 \%$. The presence of $\mathrm{Si}, \mathrm{Al}, \mathrm{Fe}, \mathrm{Li}, \mathrm{K}, \mathrm{O}, \mathrm{Mg}$ and $\mathrm{Ti}$ before adsorption are shown in Figs. 3a and 4. The $\mathrm{SiO}_{2}$ and $\mathrm{Al}_{2} \mathrm{O}_{3}$ content make up approximately $70 \%$ of the fly ash. The $\mathrm{FeO}$ and $\mathrm{CaO}$ content make up approximately $19 \%$. In Fig. 3b, the peaks at 1 and $8-10$ on the $\mathrm{keV}$ scale prove adsorption of $\mathrm{Zn}$ (II) ions by the FAN.

\section{$X$-ray diffraction studies}

The presence of $\mathrm{SiO}_{2}\left(\alpha\right.$-quartz) and $\mathrm{Al}_{2} \mathrm{O}_{3}$ was evident from the XRD patterns of the adsorbents FAN and FAN-MO (Fig. 5). The FAN and FAN-MO samples were 

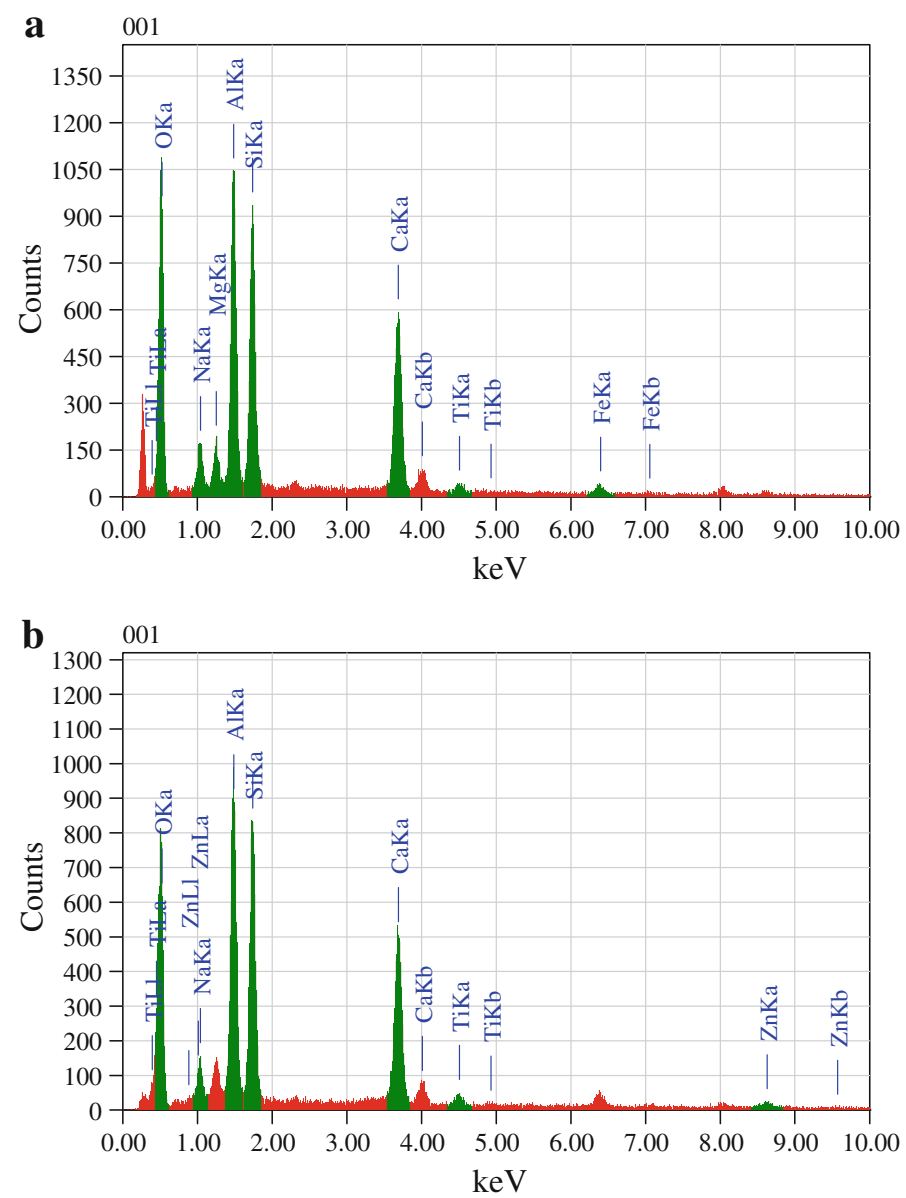

Fig. 3 a EDAX analysis of FAN before adsorption. b EDAX analysis of FAN after adsorption

exposed to $\mathrm{Cu} \mathrm{K} \alpha$ radiation $\left(k=1.54060 \AA\right.$ ) with the $2 \theta$ angle varying between $1^{\circ}$ and $70^{\circ}$. The phases were identified by comparing the peak positions and intensities with those in the Joint Committee on Powder Diffraction Standards (JCPDS) data files (Fig. 5). The peak at $21^{\circ}, 26^{\circ}$, and $50^{\circ}$ reveal the presence of silica in the form of quartz for both FAN and FAN-MO. The peak at $41^{\circ}$ shows the presence of mullite in FAN and FAN-MO.

\section{FTIR spectroscopic studies}

Surface functional groups were detected by Fourier-transform infrared (FTIR) spectroscopy in the scan range $4,000-400 \mathrm{~cm}^{-1}$. Elemental analysis was also performed.

FTIR spectra of FAN and FAN-MO contain a broad band between 3454.1 and $3448.7 \mathrm{~cm}^{-1}$ (Fig. 6a, b). This indicates the presence of hydrogen-bonded $\mathrm{OH}$ 


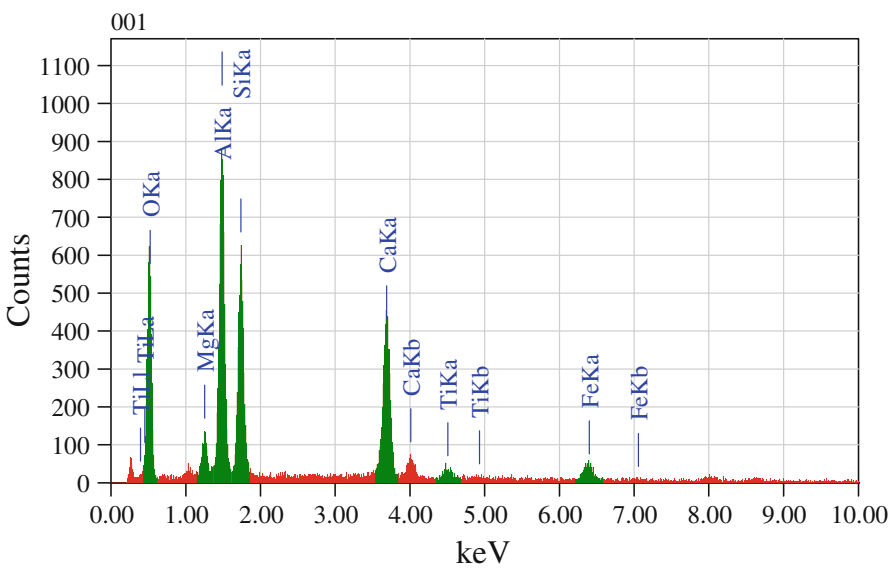

Fig. 4 EDAX analysis of FAN-MO before adsorption

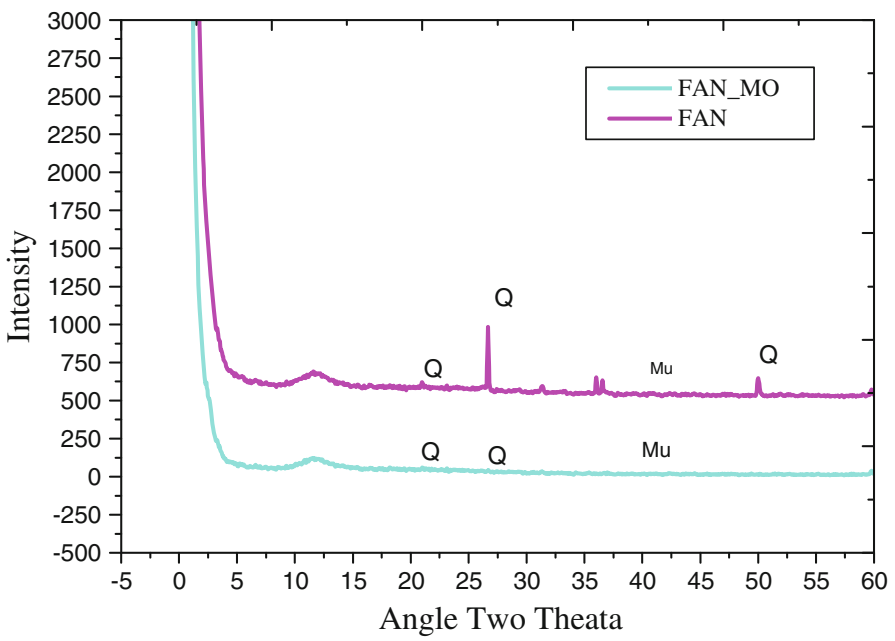

Fig. 5 XRD patterns of FAN and FAN-MO

groups, for example either water from clay minerals or phenolic groups. This stretching is both because of the silanol groups $(\mathrm{Si}-\mathrm{OH})$ and adsorbed water (peak at $3,400 \mathrm{~cm}^{-1}$ ) [32]. The FTIR spectra of FAN contained a peak at approximately 1,614 because of $\mathrm{C}=\mathrm{C}$ or $\mathrm{C}=\mathrm{O}$ aromatic ring stretching bands (aromatic carbon peaks) or aldehydes and/or ketones, respectively. The band at $1,428 \mathrm{~cm}^{-1}$ in FANMO may arise from aliphatic $\mathrm{C}-\mathrm{H}$ stretching vibrations. The FTIR of FAN-MO contained a peak at $1,113.5 \mathrm{~cm}^{-1}$ from vibration of the $\mathrm{C}=\mathrm{O}$ group in lactones [33]. Additionally, intense vibration at $558.2 \mathrm{~cm}^{-1}$ for FAN-MO is attributed to clay and silicate minerals [34]. The intense peaks associated with bonded water at 3799.6, 3854.6 , and $3840.5 \mathrm{~cm}^{-1}$ indicates that exposure of hydrolysed silica to compressive stress increased water dissolution into the silica structure as hydroxyl, for FAN 

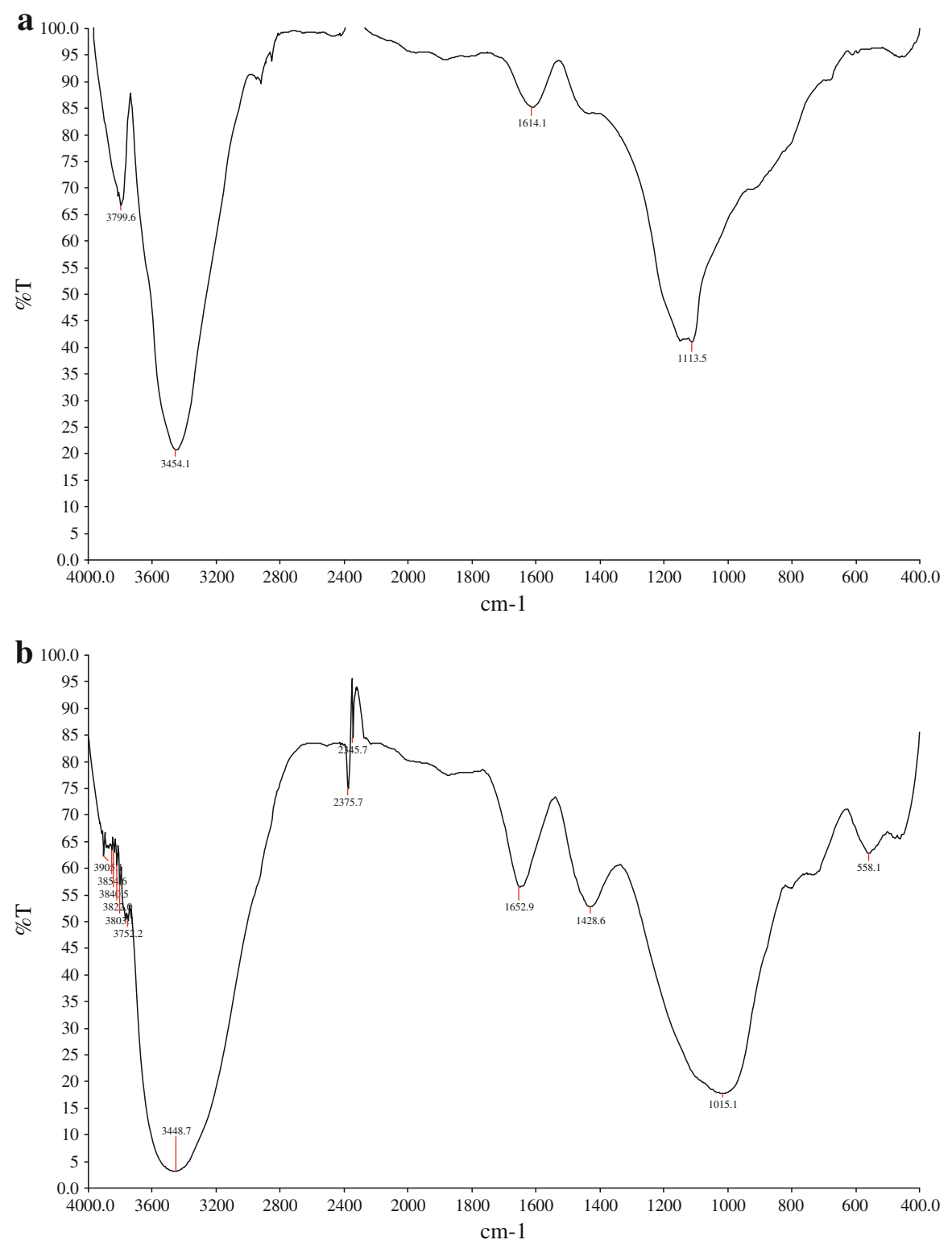

Fig. 6 a FTIR spectrum of FAN. b FTIR spectrum of FAN-MO

and FAN-MO, as expected by theory [35]. Although some inference can be drawn about the surface functional groups from FTIR spectra, the weak and broad bands do not provide any authentic information about the nature of the surface oxides. The presence of polar groups on the surface is likely to result in substantial cationexchange capacity of the adsorbents. 


\section{Iodine value of the adsorbents}

The iodine numbers of commercial adsorbents vary from 300 to $1,200 \mathrm{mg} / \mathrm{g}$. Because the iodine molecule is relatively small, iodine number can be correlated with ability to adsorb low-molecular-weight substances and provides a measure of surface area or capacity available to small molecules. The higher the iodine value, the higher will be the adsorption ability of the adsorbents. The iodine value of FAN was found to be $633.46 \mathrm{mg} / \mathrm{g}$; for FAN-MO it was $561.07 \mathrm{mg} / \mathrm{g}$. This proves the higher adsorption ability of FAN compared with FAN-MO.

Effect of $\mathrm{pH}$ on adsorption, desorption, and recycling ability

The zeta-potentials of the fly ash particles in water were measured at different $\mathrm{pH}$. It was found that the fly ash particles are positively charged at low $\mathrm{pH}$ and negatively charged at high $\mathrm{pH}$, having a point of zero charge $\left(\mathrm{pH}_{\mathrm{zpc}}\right)$ at $\mathrm{pH} 2.06$ for FAN and 3.94 for FAN-MO. Therefore, it can be expected that positively charged metal ions are likely to be adsorbed by the negatively charged fly ash particles at a $\mathrm{pH}>\mathrm{ZPC}$ for FAN and FAN-MO.

The silica in FAN and FAN-MO could adsorb either positive or negative contaminants depending on the $\mathrm{pH}$ of the solution. The central ion of silicates has electron affinity, giving the oxygen atoms bound to it low basicity. This enables the silica surface to act as a weak acid, which can react with water, forming silanol ( $\mathrm{SiOH})$ groups. As a result, at low $\mathrm{pH}$ the silica surface is positively charged and at high $\mathrm{pH}$ values it is negatively charge. The $\mathrm{pH}_{\mathrm{zpc}}$ of silica is generally approximately 2.0. Other solid material, for example iron oxide and alumina, also develops positive or negative charges depending on $\mathrm{pH}$. Iron as $\mathrm{Fe}_{2} \mathrm{O}_{3}$ has a zero point charge at $\mathrm{pH} 6.7$ whereas that of alumina is at $\mathrm{pH}_{\mathrm{zpc}} 8$ [36-38]. This indicates that the maximum $\mathrm{Zn}$ (II) ions adsorption capacity of FAN and FAN-MO can be attributed to electrostatic interaction of the ions with surface silica and iron sites. A similar effect of $\mathrm{pH}$ has previously been reported for adsorption of $\mathrm{Zn}$ (II) by fly ash [39-41].

Figure 7 indicates that the $\mathrm{pH}$ of the solution (2.0-10.0) had a significant effect on adsorption of $\mathrm{Zn}$ (II) by FAN and FAN-MO. At $\mathrm{pH} 4$, adsorption of $\mathrm{Zn}$ (II) on

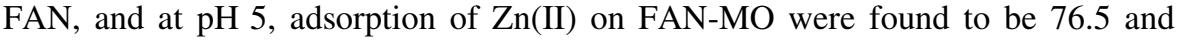
$24.7 \%$, respectively. $\mathrm{Zn}$ (II) was removed by precipitation and not adsorption if the solution $\mathrm{pH}$ was above $\mathrm{pH} 8$, for both FAN and FAN-MO [42]. Thus, we fixed the $\mathrm{pH}$ to 4.0 for FAN and $\mathrm{pH} 5.0$ for FAN-MO in this study. As shown, the precipitation of the heavy metal ions except copper was less than $20 \%$ at $\mathrm{pH}<8$, indicating that removal of the metals except copper was mainly accomplished by adsorption below $\mathrm{pH}$ 8. Because FAN has a low ZPC, the surface of the fly ash was negatively charged at the $\mathrm{pH}$ investigated. As $\mathrm{pH}$ was increased from 3 to 8 , it can be expected that the fly ash surface becomes more negatively charged. Thus, more favourable electrostatic attraction enhances cationic metal ion adsorption as $\mathrm{pH}$ is increased. However, the dependence of heavy metal adsorption on $\mathrm{pH}$ is different for each metal. The effect of $\mathrm{pH}$ on adsorption, desorption, and recycling capacities for zinc is shown in Fig. 7 for both FAN and FAN-MO. 
For FAN, the adsorption capacity increases initially to $76.5 \%$ until the $\mathrm{pH}$ reaches 4; above $\mathrm{pH} 4$, it decreases. For FAN-MO, however, the adsorption capacity increased to $24.7 \%$ at pH 5 and then decreased.

In wastewater-treatment systems using adsorption processes, regeneration of the adsorbent and/or disposal of the loaded adsorbent are very important. Desorption studies were carried out for both FAN and FAN-MO by using batch methods; the results are shown in Fig. 7. Maximum desorption of $28.4 \%$ occurred in acidic medium at $\mathrm{pH} 4$ for FAN and of $12.98 \%$ at $\mathrm{pH} 5$ for FAN-MO. The results indicate that $\mathrm{Zn}$ (II) ions adsorbed by both FAN and FAN-MO can be recovered by use of distilled water, and that the amount retrieved from FAN was higher than that from FAN-MO.

After desorption, the adsorbents were further used for adsorption of $\mathrm{Zn}$ (II) ions. The percentage removal of $\mathrm{Zn}(\mathrm{II})$ ions was found to be $12.3 \%$ for FAN at $\mathrm{pH} 4$ and $8.91 \%$ for FAN-MO at $\mathrm{pH} 5$ (Fig. 7). The increase in removal of $\mathrm{Zn}$ (II) ions at $\mathrm{pH}>8$ may be because of precipitation of metal ions in alkaline medium rather than adsorption.

\section{Effect of contact time}

Aqueous zinc metal ion solutions of initial ion concentration 100 ppm were kept in contact with FAN and FAN-MO from 5 to $60 \mathrm{~min}$. The rate of removal was rapid for the first $25 \mathrm{~min}$ for both the adsorbents; thereafter the rate of metal removal reaches equilibrium. No significant change in metal ion removal was observed after 45 min for both FAN and FAN-MO. During the initial stage of adsorption, a large number of vacant surface sites are available for adsorption. After a lapse of some time, the remaining vacant surface sites are difficult to occupy, because of repulsive forces between adsorbate molecules on the solid surface. This is shown in Fig. 8. The maximum uptake of $\mathrm{Zn}$ (II) ion by FAN at $\mathrm{pH} 4$ was $76.5 \%$ and the maximum uptake of $\mathrm{Zn}(\mathrm{II})$ ion by FAN-MO at $\mathrm{pH} 5$ was $24.7 \%$, both after an equilibration time of $50 \mathrm{~min}$.
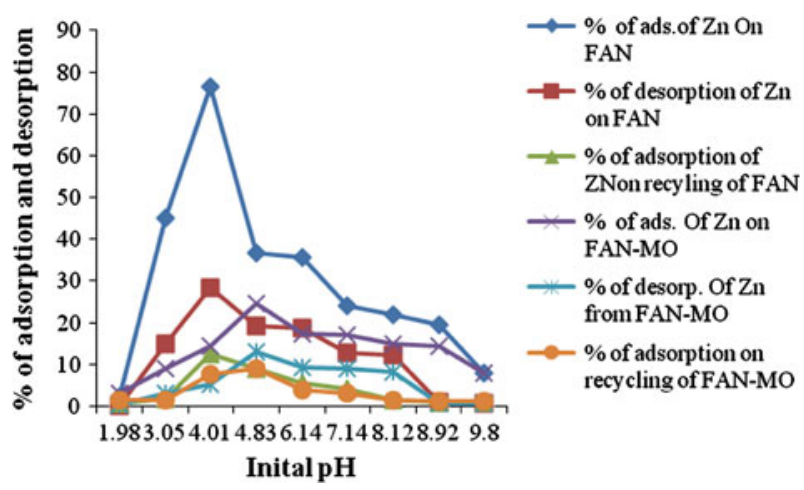

Fig. 7 Effect of $\mathrm{pH}$ on adsorption and desorption of $\mathrm{Zn}(\mathrm{II})$ ions by FAN and FAN-MO 


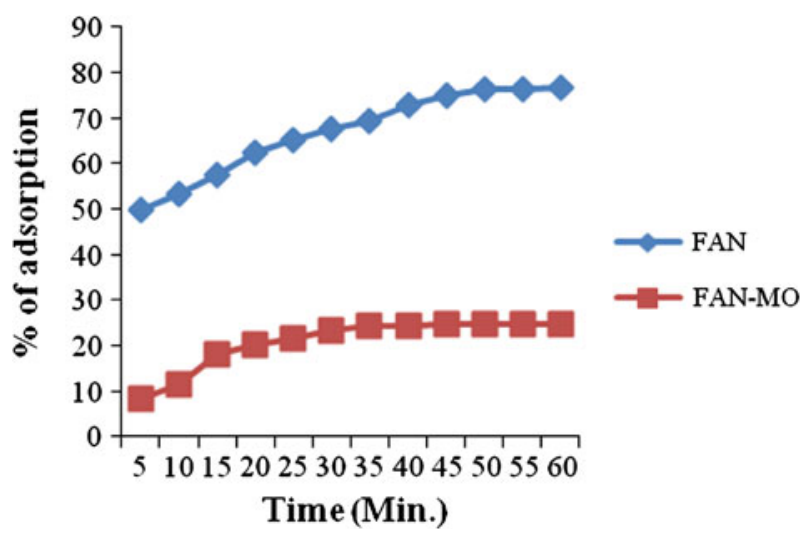

Fig. 8 Effect of contact time on adsorption

\section{Adsorption kinetics}

The adsorption process of $\mathrm{Zn}$ (II) can be well fitted by use of the pseudo-secondorder rate constant for both FAN and FAN-MO. The kinetic data are given in the Table 1. The $q_{\mathrm{e}}$ value (20.7) obtained from the second-order kinetic equation for FAN was close to the experimental $q_{\mathrm{e}}$ value (16.52), and the linear regression coefficient value $R^{2}$ value (0.9947) obtained for pseudo-second-order kinetics was closer to unity than the $R^{2}$ value $(0.964)$ for first-order kinetics. This indicates that adsorption of $\mathrm{Zn}$ (II) ions by FAN follows pseudo-second-order kinetics.

The $q_{\mathrm{e}}$ value (5.16) obtained from the second-order kinetic equation for FANMO was close to the experimental $q_{\mathrm{e}}$ value (7.7) and the linear regression coefficient value $\left(R^{2}\right.$ value 0.9846$)$ obtained for pseudo-second-order kinetics was closer to unity than the $R^{2}$ value $(0.8468)$ for first-order kinetics. This indicates that adsorption of $\mathrm{Zn}$ (II) ions by FAN-MO follows pseudo-second-order kinetics.

When the Elovich equation was used, the linear coefficient for FAN was found to be 0.9598 whereas it was 0.944 for FAN-MO. The Elovich constants $A_{\mathrm{E}}$ and $B_{\mathrm{E}}$ for FAN were $0.3378 \mathrm{mg} / \mathrm{g}$ min and $1.073 \mathrm{~g} / \mathrm{min}$ respectively. The Elovich constants $A_{\mathrm{E}}$ and $B_{\mathrm{E}}$ for FAN-MO were $0.57 \mathrm{mg} / \mathrm{g}$ min and $3.81 \mathrm{~g} / \mathrm{min}$ respectively. These values were also better for FAN than for FAN-MO, which proves the suitability of the Elovich equation for FAN.

In the intraparticle diffusion model, the values of $q_{\mathrm{t}}$ were found to be linearly correlated with the values of $t^{1 / 2}$. The $K_{\mathrm{d}}$ values were calculated by use of correlation analysis. $K_{\mathrm{d}}=1.3, R^{2}=0.9864$ for FAN and $K_{\mathrm{d}}=0.73, R^{2}=0.9861$ for FAN. The $R^{2}$ values were closer to unity for FAN than for FAN-MO, indicating the application of this model is a better fit for FAN than for FAN-MO. This reveals the presence of an intra-particle diffusion process in FAN.

Effect of adsorbent dose

Figure 9 indicates that the maximum adsorption capacity of FAN at $\mathrm{pH} 4$ is $76.5 \%$ and that at $\mathrm{pH} 5$ for FAN-MO is $24.7 \%$. This is because of the increase in adsorption sites as the dose is increased from 0.2 to $1 \mathrm{~g}$. 


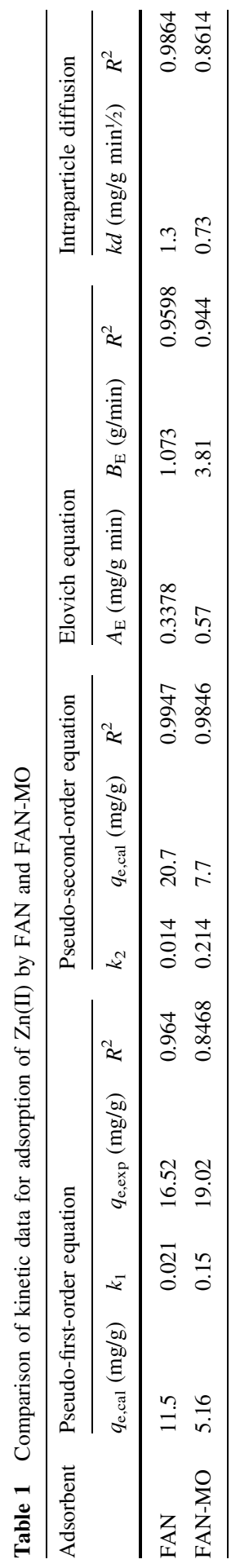




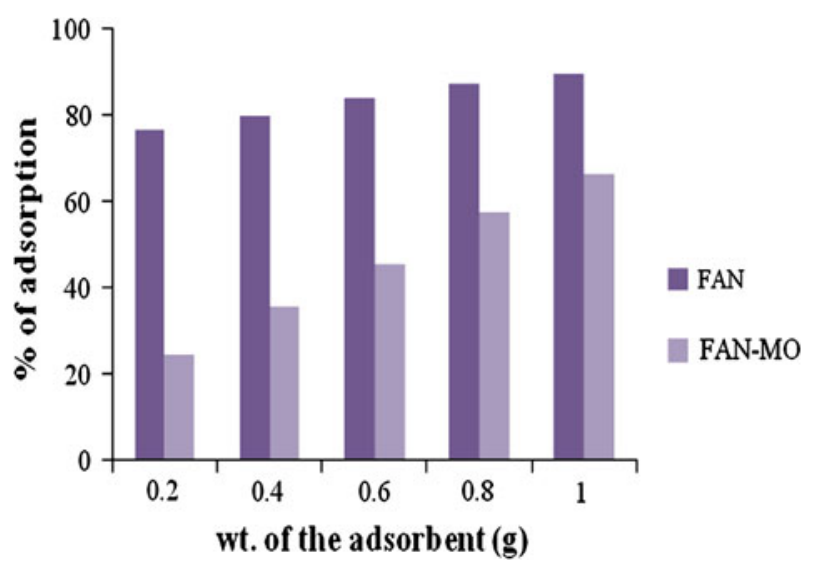

Fig. 9 Effect of dose on adsorption of $\mathrm{Zn}(\mathrm{II})$ ions

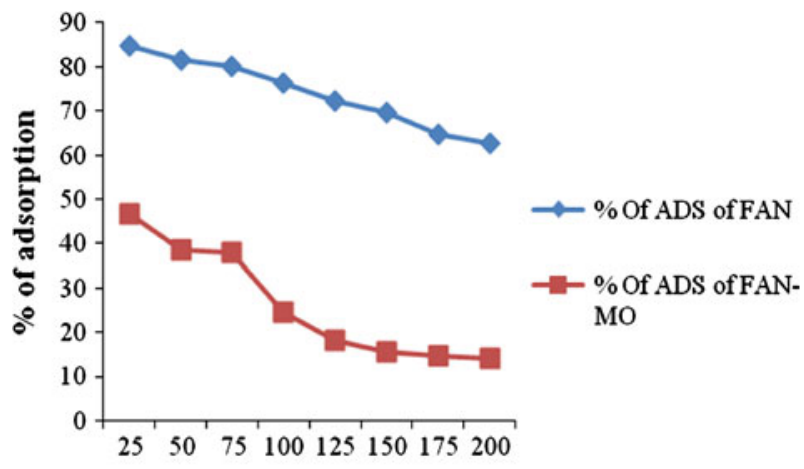

Initial metal concentration in ppm

Fig. 10 Effect of $\mathrm{Zn}$ (II) ion concentration on adsorption by FAN and FAN-MO

Effect of $\mathrm{Zn}(\mathrm{II})$ ion concentration on adsorption

The initial metal concentration is an important driving force; hence, a higher initial concentration of metal ions will increase the sorption rate. The effect of changing the initial concentration of zinc ions on adsorption, while keeping the dosage of FAN and FAN-MO constant at room temperature and equilibrium $\mathrm{pH}$ is illustrated in Fig. 10. As the concentration of $\mathrm{Zn}$ (II) ions was increased from 25 to $200 \mathrm{ppm}$, the percentage adsorption decreased. The percentage adsorption for FAN was reduced to $62.5 \%$ and that for FAN-MO was reduced to $14.06 \%$. This was because of the increase in concentration of $\mathrm{Zn}(\mathrm{II})$ ions for a smaller number of adsorption sites.

Adsorption isotherm

To optimize the design of an adsorption system, it is important to establish the most appropriate isotherm model. Different isotherm equations (Langmuir, Freundlich, 
Tempkin, Dubinin-Radushkevich, Harkin-Jura and Frenkel-Halsey) were used to describe the mono-component equilibrium characteristics of adsorption of $\mathrm{Zn}$ (II) ions by FAN and FAN-MO. The experimental equilibrium adsorption data were obtained by varying the concentration of $\mathrm{Zn}$ (II) ions with fixed amounts of FAN and FAN-MO.

The adsorption data obtained by fitting the different isotherm models with the experimental data are listed in Table 2, with the linear regression coefficients, $R^{2}$. FAN and FAN-MO have a homogeneous surface for adsorption of metal ions. The Langmuir isotherm equation is therefore expected to best represent the equilibrium adsorption data. The $R^{2}$ values for the Langmuir model are closer to unity than those for the other isotherm models for both FAN $\left(R^{2}=0.9957\right)$ and FAN-MO $\left(R^{2}=0.9768\right)$. Therefore, the equilibrium adsorption of $\mathrm{Zn}(\mathrm{II})$ ions on FAN and FAN-MO can be represented appropriately by the Langmuir model in the concentration range studied.

Table 2 Isotherm constants and coefficients of determination for FAN and FAN-MO

\begin{tabular}{|c|c|c|}
\hline Isotherm model & FAN & FAN-MO \\
\hline \multicolumn{3}{|l|}{ Langmuir } \\
\hline$Q_{\mathrm{m}}(\mathrm{mg} / \mathrm{g})$ & 15.06 & 3.13 \\
\hline$K_{\mathrm{a}}(1 / \mathrm{mg})$ & 0.3076 & 0.0426 \\
\hline$R^{2}$ & 0.9957 & 0.9768 \\
\hline \multicolumn{3}{|l|}{ Freundlich } \\
\hline $1 / n$ & 0.1 & 0.5293 \\
\hline$K_{\mathrm{F}}(\mathrm{mg} / \mathrm{g})$ & 24.67 & 54.53 \\
\hline$R^{2}$ & 0.8516 & 0.9174 \\
\hline \multicolumn{3}{|l|}{ Tempkin } \\
\hline$\alpha(1 / g)$ & 6.5387 & 21.03 \\
\hline$\beta(\mathrm{mg} / \mathrm{l})$ & 1.7939 & 3.5091 \\
\hline$b$ & 1.4043 & 717.89 \\
\hline$R^{2}$ & 0.8684 & 0.9494 \\
\hline \multicolumn{3}{|l|}{ Dubinin-Radushkevich } \\
\hline$Q_{\mathrm{m}} \mathrm{mg} / \mathrm{g}$ & 17.45 & 4.9249 \\
\hline$K\left(\times 10^{-5} \mathrm{~mol}^{2} / \mathrm{KJ}^{2}\right)$ & 0.05 & 3 \\
\hline$E\left(\mathrm{~kJ} \mathrm{~mol}^{-1}\right)$ & 1 & 0.13 \\
\hline$R^{2}$ & 0.3154 & 0.4727 \\
\hline \multicolumn{3}{|l|}{ Harkin-Jura } \\
\hline$R^{2}$ & 0.8132 & 0.8089 \\
\hline$A$ & 666.67 & 13.495 \\
\hline$B$ & 0.8 & 1.27 \\
\hline \multicolumn{3}{|l|}{ Frenkel-Halsey-Hill } \\
\hline$R^{2}$ & 0.8516 & 0.9197 \\
\hline $1 / n$ & 0.1 & 0.5293 \\
\hline$K$ & $8.32 \times 10^{13}$ & $1.91 \times 10^{3}$ \\
\hline
\end{tabular}




\section{Column studies}

Breakthrough capacity curves are important in process design because they are directly related to the feasibility and economics of a given process [43]. The time taken for elution is much less than for batch mode studies, in which it took $1 \mathrm{~h}$ to achieve equilibrium. Figure 11 shows that $50 \mathrm{~mL} \mathrm{Zn(II)} \mathrm{ion} \mathrm{solution} \mathrm{(100} \mathrm{ppm)} \mathrm{at}$ $\mathrm{pH} 4$ for FAN and $50 \mathrm{~mL} \mathrm{Zn(II)} \mathrm{ion} \mathrm{solution} \mathrm{(100} \mathrm{ppm)} \mathrm{at} \mathrm{pH} 5$ for FAN-MO could be passed through a column without any $\mathrm{Zn}$ (II) ions being detected in the effluent when $0.2 \mathrm{~g}$ adsorbent was used. The results obtained at $5 \mathrm{~mL} / \mathrm{min}$ were calculated from the breakthrough curve. By use of Eq. (12) the retention volume of the analyte $\left(V_{\mathrm{R}}\right)$ was determined to be $43.63 \mathrm{~mL}$ for FAN and $42.94 \mathrm{~mL}$ for FAN-MO corresponding to the volume respect to the half the initial concentration [44].

$$
V_{\mathrm{R}}=0.5 C_{\mathrm{o}}
$$

The breakthrough volume $\left(V_{\mathrm{B}}\right)$ is usually defined as:

$$
V_{\mathrm{B}}=V_{\mathrm{R}}-2 \sigma_{v}
$$

where $\sigma_{v}$ is the standard deviation which can be determined graphically from the breakthrough curve. $\sigma_{v}$ is directly related to the efficiency of the solid phase extraction column, i.e. the number of theoretical plates $(N)$, which can be calculated from the breakthrough curve shown in Fig. 11 by use of the equation:

$$
N=V_{\mathrm{R}}\left(V_{\mathrm{R}}-\sigma_{v}\right) / \sigma_{v}^{2}
$$

The capacity factor of the solute $(k)$, can be calculated from the fundamental equation of chromatography:

$$
k=\frac{V_{\mathrm{R}}}{V_{\mathrm{B}}}-1
$$

The recovery factor ' $r$ ' can also directly related to the breakthrough curve. The recovery factor can now be calculated by using the equation:

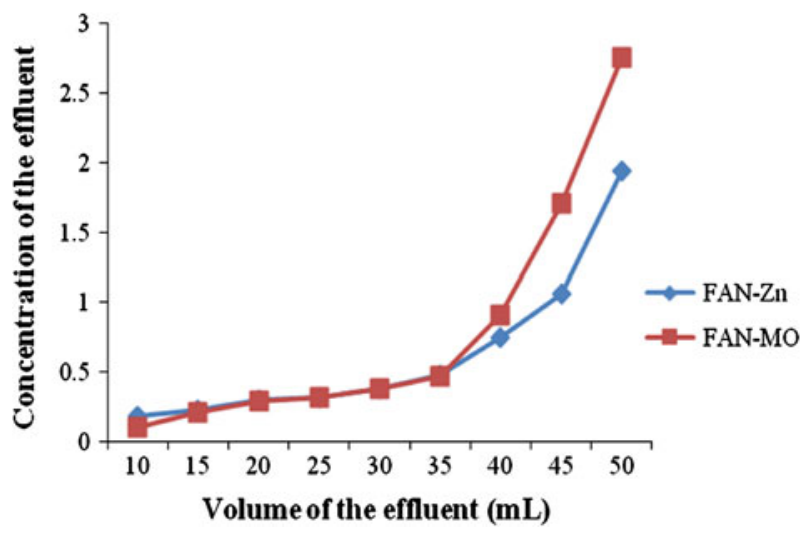

Fig. 11 Breakthrough capacity of FAN and FAN-MO 
Table 3 Column chromatographic data calculated for FAN and FAN-MO for adsorption of Zn(II)ions

\begin{tabular}{lllllll}
\hline & $V_{\mathrm{B}}(\mathrm{mL})$ & $V_{\mathrm{R}}(\mathrm{mL})$ & $V_{\mathrm{M}}(\mathrm{mL})$ & $N$ & $r(\%)$ & Percentage desorption $(0.1 \mathrm{M} \mathrm{HCl})$ \\
\hline FAN-MO & 22.08 & 42.94 & 11 & 12.83 & 63.89 & 7.51 \\
FAN & 1.49 & 43.63 & 10 & 657 & 67.26 & 6.29 \\
\hline
\end{tabular}

$$
r=\frac{V_{\mathrm{M}} k}{V_{o}} \times 100 \%
$$

where $V_{\mathrm{M}}$ represents the hold up volume of the solid phase extraction cartridge. The values calculated by use of these relationships for both FAN and FAN-MO are given in the Table 3 .

Several solvents (acids, bases and water) were used in the desorption experiments. Column desorption experiments were carried out and desorption efficiencies are compared in Fig. 12. Desorption with $0.1 \mathrm{M} \mathrm{HCl}$ was found to be $7.51 \%$ for FAN, which was higher than for other desorbing agents used. Desorption with $0.1 \mathrm{M} \mathrm{HCl}$ was found to be $6.29 \%$ for FAN-MO, which was higher than for other desorbing agents.

Effect of other metals on adsorption of $\mathrm{Zn}(\mathrm{II})$ ions

Effect of $\mathrm{Ni}(\mathrm{II})$ ions and $\mathrm{Cu}(\mathrm{II})$ ions on adsorption of $\mathrm{Zn}(\mathrm{II})$ ions (binary system)

The concentration of the $\mathrm{Zn}$ (II) ion solution was kept as $100 \mathrm{ppm}$. The concentration of $\mathrm{Cu}$ (II) ion was varied as 10, 20, 30, and $40 \mathrm{ppm}$. Each solution was placed in a bottle with FAN and the $\mathrm{pH}$ was adjusted to 4. After shaking for 50 min percentage adsorption was calculated. Percentage adsorption decreased from 76.24 to $45.03 \%$ as the concentration of $\mathrm{Cu}(\mathrm{II})$ solution was increased. This showed competitive adsorption was, to some extent, taking place between the $\mathrm{Zn}$ (II) ions and the $\mathrm{Cu}$ (II) ions. The same procedure was repeated for $\mathrm{Zn}$ (II) ions in presence of $\mathrm{Ni}(\mathrm{II})$ ions. The percentage adsorption of $\mathrm{Zn}$ (II) ions decreased to 76.24-47.9\% in the presence of $\mathrm{Ni}(\mathrm{II})$ ions. This is clearly shown in Fig. 13 for FAN. When the same procedure was repeated for FAN-MO at $\mathrm{pH} 5$, adsorption decreased to

Fig. 12 Efficiency of desorption of $\mathrm{Zn}$ (II)ions from FAN and FAN-MO by different desorbing agents

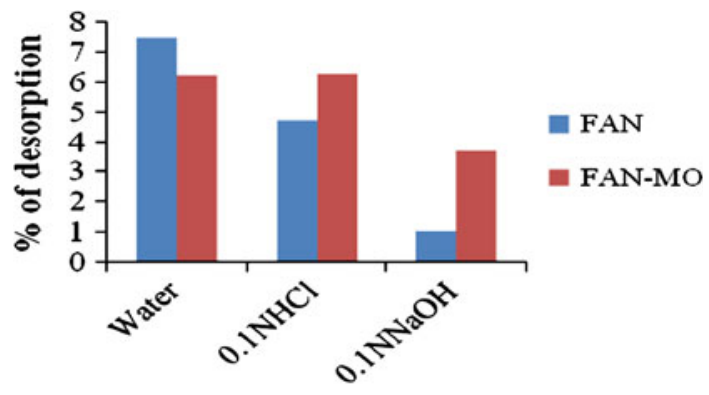

Desorbing agents 


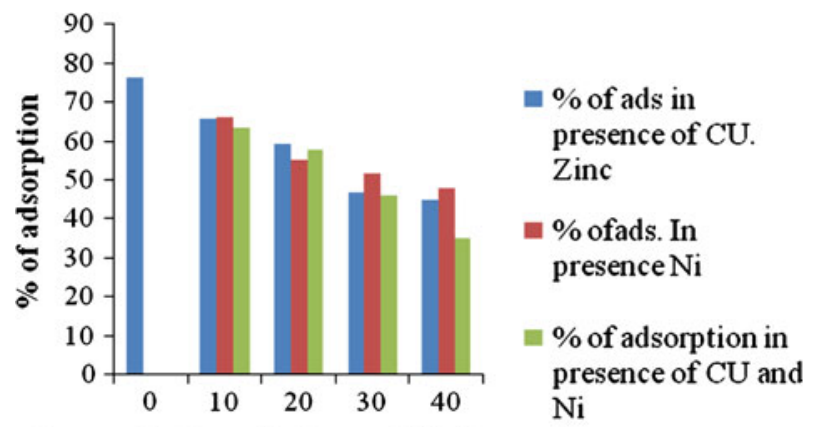

Comcentration of other metals (in ppm)

Fig. 13 Effect of $\mathrm{Ni}(\mathrm{II})$ ions and $\mathrm{Cu}(\mathrm{II})$ ions on adsorption on to FAN

$24.7-15.23 \%$ in the presence of $\mathrm{Cu}$ (II) ions and to $24.7-13.45 \%$ in presence of $\mathrm{Ni}(\mathrm{II})$ ions. This is clearly shown in Fig. 14.

Effect of $\mathrm{Ni}(\mathrm{II})$ ions and $\mathrm{Cu}(\mathrm{II})$ ions and $\mathrm{Ni}(\mathrm{II})$ ions on adsorption of $\mathrm{Zn}(\mathrm{II})$ ions (tertiary system)

The concentration of $\mathrm{Zn}$ (II) ion solution was kept as $100 \mathrm{ppm}$. The concentrations of $\mathrm{Ni}(\mathrm{II})$ and $\mathrm{Cu}(\mathrm{II})$ ion solutions were varied as 10, 20, 30, and $40 \mathrm{ppm}$. Solutions of both $\mathrm{Ni}$ (II) ions and $\mathrm{Cu}$ (II) ions were added to $\mathrm{Zn}$ (II) solution in a bottle with FAN and the $\mathrm{pH}$ was adjusted to 4 . After shaking $1 \mathrm{~h}$ percentage adsorption was calculated. Percentage adsorption decreased from 76.24 to $34.88 \%$ as the concentrations of $\mathrm{Ni}$ (II) ions and $\mathrm{Cu}$ (II) ions were increased. This showed competitive adsorption was, to some extent, taking place between the $\mathrm{Ni}$ (II) ions, the $\mathrm{Cu}(\mathrm{II})$ ions, and the $\mathrm{Zn}$ (II) ions. Percentage adsorption of $\mathrm{Zn}$ (II) was reduced in the presence of the other metals, as is clearly shown in Fig. 13. The same procedure was repeated for FAN-MO at $\mathrm{pH} 5$ and percentage adsorption decreased from 24.7 to $14.12 \%$, as illustrated in Fig. 14.

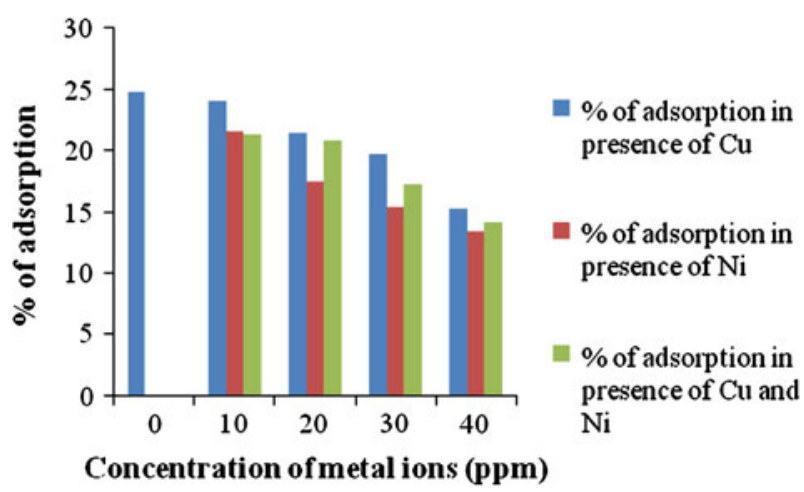

Fig. 14 Effect of $\mathrm{Ni}(\mathrm{II})$ ions and $\mathrm{Cu}(\mathrm{II})$ ions on adsorption on to FAN 


\section{Conclusion}

Treatment of fly ash with alkali, e.g. $4 \mathrm{M} \mathrm{NaOH}$ solution, modifies the surface by dissolution and reprecipitation reactions. By dissolution of acid oxides, the specific surface area is enhanced and activated and the efficiency of heavy metal removal increases. Adding dye to the fly ash surface results in a new surface, which is more homogeneous but less negatively charged. The overall effect is a decrease in affinity for heavy metals.

Adsorption of $\mathrm{Zn}$ (II) ions is $\mathrm{pH}$-dependent, with maximum adsorption of $76.24 \%$ occurring at $\mathrm{pH} 4$ for FAN and of $24.7 \%$ at $\mathrm{pH} 5$ for FAN-MO. The adsorption data were well fitted by the Langmuir isotherm model; this is indicative of monolayer adsorption by FAN and FAN-MO. Adsorption of $\mathrm{Zn}$ (II) ions by FAN and FAN-MO obeyed pseudo-second-order kinetics. Adsorbed $\mathrm{Zn}$ (II) ions can be desorbed from both the adsorbents by use of $0.1 \mathrm{M} \mathrm{HCl}-7.51 \%$ of adsorbed $\mathrm{Zn}$ (II) ions were recovered from FAN and $6.29 \%$ of adsorbed $\mathrm{Zn}(\mathrm{II})$ ions were recovered from FAN-MO. Percentage adsorption of $\mathrm{Zn}(\mathrm{II})$ ions on FAN and FAN-MO was higher in the single-ion systems ( $\mathrm{Zn}$ (II) ions only) than in binary and tertiary systems (containing $\mathrm{Zn}$ (II), $\mathrm{Ni}(\mathrm{II})$, and $\mathrm{Cu}$ (II) ions), which is indicative of competitive adsorption among the metal ions. Compared with FAN-MO, FAN had higher adsorption capacity for removal of $\mathrm{Zn}$ (II) ions from aqueous solution. In column studies, the efficiency of removal of $\mathrm{Zn}$ (II) ions was less than in batch mode for both FAN and FAN-MO, but the time taken for adsorption was 10 min only. Under these conditions we found the column study was not as suitable as batch mode studies for removal of $\mathrm{Zn}(\mathrm{II})$ ions by FAN and FAN-MO. The results show this experiment can be scaled up and is a step in investigation of the process of complex treatment of wastewater containing dyes and heavy metals.

Open Access This article is distributed under the terms of the Creative Commons Attribution License which permits any use, distribution, and reproduction in any medium, provided the original author(s) and the source are credited.

\section{References}

1. S.V. Mattigod, D. Rai, L.E. Eary, C.C. Ainsworth, Geochemical factors controlling the mobilization of inorganic constituents from fossil fuel combustion residues. I. Review of the major elements. J. Environ. Qual. 19(2), 188-201 (1990)

2. S. Jala, D. Goyal, Fly ash as a soil ameliorant for improving crop production- review. Bioresour. Technol. 97(9), 1136-1146 (2006)

3. S.K. Antiohos, S. Tsimas, A novel way to upgrade the coarse part of high calcium fly ash for reuse into cement systems. Waste Manag 27(5), 675-683 (2007)

4. S.K. Antiohos, V.G. Papadakis, E. Chaniotakis, S. Tsimas, Improving the performance of ternary blended cements by mixing different types of fly ashes. Cem. Concr. Res. 37(6), 877-885 (2007)

5. D.C. Adriano, A.L. Page, A.A. Elseewi, A.C. Chang, I. Straughan, Utilization and disposal of fly ash and other coal residues in terrestrial ecosystems: a review. J. Environ. Qual. 9(3), 333-344 (1980)

6. C.L. Carlson, D.C. Adriano, Environmental impacts of coal combustion residues. J. Environ. Qual. 22(2), 227-247 (1993)

7. M. Visa, L. Isaac, A. Duta, Fly ash-activated carbon powder for dyes and heavy metals removal. Adv. Mater. Res. 79-82, 243 (2009)

8. M. Visa, A. Luminita, A. Duta, Advanced treatment of wastewater with methyl orange and heavy metals on $\mathrm{TiO}_{2}$, fly ash and their mixtures. J. Catal. Today 144(1-2), 137-142 (2009) 
9. St. Albanese, M.L. De Luca, B. De Vivo, A.M. Lima, G. Grezzi, Relationships between heavy metal distribution and cancer mortality rates in the Campania region, Italy. Environ. Geochem. 391-403 (2008)

10. P. Battistoni, G. Fava, L.M. Ruello, Heavy metal shush load in activated sludge uptake and toxic effects. Water Res. 27, 821-827 (1993)

11. H.A. Aziz, M.N. Adlan, K.S. Ariffin, Heavy metals (Cd, Pb, $\mathrm{Zn}, \mathrm{Ni}, \mathrm{Cu}$ and $\mathrm{Cr}$ (III) removal from water in Malaysia: post treatment by high quality limestone. Bioresour. Technol. 99, 1578-1583 (2008)

12. V.K. Gupta, J. Ali, Removal of lead and chromium from wastewater using bagasse fly ash-a sugar industry waste. J. Colloid Interface Sci. 271, 312-328 (2004)

13. Y.N. Mata, M.L. Blázquez, A. Ballester, F. González, J.A. Muñoz, Sugar beet pulp pectin gels as biosorbent for heavy metals: preparation and determination of biosorption and desorption characteristics. Chem. Eng. J. 150, 289-301 (2009)

14. D. Mohan, P.K. Singh, Single and multicomponent adsorption of cadmium and zinc using activated carbon derived from bagasse-an agricultural waste. Water Res. 36, 2304-2318 (2002)

15. L.J. Yu, S.S. Shukla, K.L. Dorris Ca, B. Shukla, J.L. Margrave, Adsorption of chromium from aqueous solutions by maple saw dust. J. Hazard. Mater. 100, 53-63 (2003)

16. D. Ozdes, C. Duran, H.B. Senturk, Adsorption removal of $\mathrm{Cd}(\mathrm{II})$ and $\mathrm{Pb}(\mathrm{II})$ ions from aqueous solutions by using Turkish illitic clay. J. Environ. Manag. 92(12), 3082-3090 (2011)

17. L.-n. Shi, X. Zhang, Z.-1. Chen, Removal of chromium(VI) from wastewater using bentonite-supported nanoscale zero-valent iron. Water Res. 45, 886-892 (2011)

18. C.W. Cheung, J.F. Porter, G. Mckay, Sorption kinetic analysis for the removal of cadmium ions from effluents using bone char. Water Res. 35, 605-612 (2001)

19. S. Wang, T. Terdkiatburana, M.O. Tadé, Single and co-adsorption of heavy metals on humic acid. Sep. Purif. Technol. 58, 353-358 (2008)

20. Y.S. Ho, G. McKay, Sorption of copper(II) from aqueous solution by peat. Water Air Soil Pollut. 158, 77-97 (2004)

21. J. Perić, M. Trgo, N.V. Medvidović, Removal of zinc, copper and lead by natural zeolite-a comparison of adsorption isotherms. Water Res. 38, 1893-1899 (2004)

22. T.-C. Hsu, Y. Chung-Chin, C.-M. Yeh, Adsorption of $\mathrm{Cu}(\mathrm{II})$ from water using raw and modified coal fly ashes. Fuel 87, 1355-1359 (2008)

23. I. Langmuir, The constitution and fundamental properties of solids and liquids. J. Am. Chem. Soc. 38, 2221-2295 (1916)

24. H. Freundlich, Über die adsorption in Lösungen (adsorption in solution). Z. Phys. Chem. 57, 384-470 (1906)

25. M.I. Tempkin, V. Pyzhev, Kinetics of ammonia synthesis on promoted iron catalyst. Acta Phys. Chim. USSR 12, 327-356 (1940)

26. M.M. Dubinin, The potential theory of adsorption of gases and vapors for adsorbents with energetically non-uniform surface. Chem. Rev. 60, 235-266 (1960)

27. M.M. Dubinin, Modern state of the theory of volume filling of micropore adsorbents during adsorption of gases and steams on carbon adsorbents. Zh. Fiz. Khim. 39, 1305-1317 (1965)

28. L.V. Radushkevich, Potential theory of sorption and structure of carbons, Zh. Fiz. Khim. 23, 1410-1420 (1949)

29. S. Kundu, A.K. Gupta, Investigation on the adsorption efficiency of iron oxide coated cement (IOCC) towards As(V)-kinetics, equilibrium and thermodynamic studies. Colloid Surf. A 273, 121-128 (2006)

30. C.A. Basker, Applicability of the various adsorption models of three dyes adsorption on to activated carbon prepared waste apricot. J. Hazard. Mater. 135B, 232-241 (2006)

31. J. Halsey, Chem. Phys. 16, 931 (1948)

32. Y.M. Hsieh, M.S. Tsai, F.S. Yen, Pore size and adsorption capacity of unburned carbon affected by gasification with carbon dioxide. J. Environ. Sci. Health A 39, 2143-2155 (2000)

33. M. Nogami, M. Tomozawa, J. Am. Ceram. Soc. 67, 151 (1984)

34. B. Bayat, Combined removal of $\mathrm{Zn}(\mathrm{II})$ and $\mathrm{Cd}(\mathrm{II})$ from aqueous solutions by adsorption on to highcalcium Turkish fly ash. Water Air Soil Pollut. 136, 69-92 (2002)

35. B. Bayat, Comparative study of adsorption properties of Turkish fly ashes. I. The case of Ni(II), $\mathrm{Cu}(\mathrm{II})$ and $\mathrm{Zn}(\mathrm{II})$. J. Hazard. Mater. 3897, 1-23 (2002)

36. B. Bayat, Comparative study of adsorption properties of Turkish fly ashes. II. The case of $\mathrm{Cr}(\mathrm{VI})$ and Cd(II). J. Hazard. Mater. 3898, 1-16 (2002) 
37. V.K. Gupta, C.K. Jain, I. Ali, M. Sharma, V.K. Saini, Removal of cadmium and nickel from wastewater using bagasse fly ash—a sugar industry waste. Water Res. 37, 4038-4044 (2003)

38. V.K. Gupta, D. Mohan, S. Sharma, K.T. Park, Removal of Cr(VI) from electroplating industry waste water using bagasse fly ash—a sugar industry waste material. Environmentalist 19, 129-136 (1999)

39. M. Rao, A.V. Parwate, A.G. Bhole, Removal of $\mathrm{Cr}(\mathrm{VI})$ and Ni(II) from aqueous solution using bagasse and fly ash. Waste Manag. 22, 821-830 (2002)

40. V. HeÂA quet, P. Ricou, I. Lecuyer, P. Le Cloirec, Removal of $\mathrm{Cu}(\mathrm{II})$ and $\mathrm{Zn}$ (II) in aqueous solutions by sorption on to mixed fly ash. Fuel 80, 851-856 (2001)

41. V.K. Gupta, I. Ali, Removal of lead and chromium from wastewater using bagasse fly ash-a sugar industry waste. J. Colloid Interface Sci. 271, 321-328 (2004)

42. S.E. Bailey, T.J. Olin, R. Mark Bricka, D. Dean Adrian, A review of potentially low-cost sorbents for heavy metals. Water Res. 33(11), 2469-2479 (1999)

43. R.A.K. RaO, M.A. Khan, F. Rehman, Batch and column studies for the removal of lead(II) ions from aqueous solution on to lignite 29(1), 83-98 (2011)

44. A. Gelencser, G. Kiss, Z. Krivacsy, Z. Varga-Puchony, J. Chromatogr. A 693, 217 (1995) 